\title{
The Diversity of Endophytic Bacteria from the Traditional Medicinal Plants Leaves that Have Anti-phytopathogens Activity
}

\author{
Syukria Ikhsan Zam ${ }^{1 *}$, Anthoni Agustien ${ }^{2}$, Syamsuardi ${ }^{2}$, Akmal Djamaan ${ }^{3}$, Irfan Mustafa ${ }^{4}$ \\ ${ }^{1}$ Agrotechnology Department, Faculty of Agriculture and Animal Science, State Islamic University of Sultan \\ Syarif Kasim Riau, Pekanbaru 28293, Indonesia \\ 2 Biology Department, Faculty of Mathematics and Natural Sciences, Andalas University, Padang 25163, \\ Indonesia \\ ${ }^{3}$ Faculty of Pharmacy, Andalas University, Padang 25163, Indonesia \\ ${ }^{4}$ Biology Department, Faculty of Mathematics and Natural Sciences, Brawijaya University, Malang 65145, \\ Indonesia
}

Article history:

Submission August 2018

Revised September 2018

Accepted November 2018

*Corresponding author:

E-mail:

syukria.ikhsan.zam@uin-suska.ac.id

\begin{abstract}
Endophytic bacteria live in plant tissues which utilized in plant protection against phytopathogens. This study aims to investigate the diversity of endophytic bacteria from the leaves of traditional medicinal plants that has anti-phytopathogens properties. Isolation of endophytic bacteria was done by spread plate method. The bacteria were characterised by Gram staining and the 16S rRNA gene analysis. Further screening of anti-phytopathogen activity used disc diffusion method for Ralstonia solanacearum, Xanthomonas campestris, Fusarium oxysporum, and Sclerotium rolfsii. All togethers, sixteen isolates of endophytic bacteria from the leaves of eight medicinal plants species were obtained. Fourteen isolates had an anti-phytopathogen (with eight isolates against $R$. solanacearum, seven isolates against $X$. campestris, nine isolates against $F$. oxysporum, and five isolates against $S$. rolfsii). From the 14 isolates identified, phylum Firmicutes were dominant (64.3\%), followed by Proteobacteria (28.6\%), and Actinobacteria (7.1\%). Phylum Firmicutes consists of Bacillus indicus (BJF1, TCF1, and MCF2), Bacillus pumilus (CAF4), Bacillus sp. (CAF1), Bacillus subtilis (AAF2, MCF1, CAF3, and MCF3); phylum Proteobacteria consists of Pantoea agglomerans (CAF2), Pantoea stewartii (AAF4), Pseudomonas oryzihabitans (AAF3), and Pseudomonas psychrotolerans (AAF1); and phylum Actinobacteria consists of Kocuria kristinae (CSF1).
\end{abstract}

Keywords: Diversity, endophytic bacteria, traditional medicinal plants, antimicrobial activity, anti-phytopathogens activity

\section{Introduction}

Endophytic bacteria which live in plant tissues is a very interesting subject to study. This organism significantly involves in the protection of plants, increasing growth, and overcoming environmental stresses [1, 2].

Traditional medicinal plants [such as Annona muricata L., Artocarpus altilis (Parkinson) Fosberg, Brucea javanica (L.) Merr., Citrus aurantifolia Swingle, Cheilocostus speciosus (J. Konig) C. Specht, Datura metel L., Manilkara zapota (L.) P. Royen, Morinda citrifolia L., Syzygium cumini
(L.) Skeels., and Tinospora crispa (L.) Miers] have been widely reported to have antimicrobial activity against human pathogen and phytopathogen.

Endophytic bacteria isolated from traditional medicinal plants are reported to produce antibacterial, antifungal and antiseptic compounds [3, 4]. These compounds have the potential to be utilized as biopesticides in controlling pests and diseases in plants.

The use of endophytic bacteria as a biopesticide producer is very beneficial for the environ- 
ment. Biopesticide compounds are more environmentally friendly than synthetic pesticides. This is because biopesticides are easily decomposed in nature, specific work targets, have unique properties and work methods, and are not toxic to humans [5].

Ralstonia solanacearum (causes of plant wilt) [6], Xanthomonas campestris (causes of plant blight) [7], Fusarium oxysporum (cause of plant wilt) [8], and Sclerotium rolfsii (cause of root rot) [9] are important phytopathogens for plants. These phytopathogens are soil-borne which quite difficult to control. As phytopathogen resistance increases to existing pesticides, it is necessary to continue to explore in finding new strains of endophytic bacteria that have the potential to be developed as biopesticide producers. This study aims to investigate the diversity of endophytic bacteria from the leaves of medicinal plants that can inhibit the growth of phytopathogens.

\section{Material and Methods Isolation of endophytic bacteria}

Leaves of plants A. muricata L., Art. altilis (Parkinson) Fosberg, B. javanica (L.) Merr., C. aurantifolia Swingle, Che. speciosus (J. Konig) C. Specht, D. metel L., M. zapota (L.) P Royen, Mor. citrifolia L., S. cumini (L.) Skeels., and T. crispa (L.) Miers were collected from the garden in Lakuk, Simpang Haru Village, Padang, West Sumatra Province, Indonesia. The collection of plant leaves was carried out according to de Melo et al. (2009) [10]. Leaves were sterilized by following the method developed by Araujo et al. (2001) [11]

Isolation was carried out using the method of de Melo et al. (2009) [10] with modification. Sterile plant leaf segments (1 gram) were mashed with a mortar and sterile pestle, then suspended into 9 $\mathrm{mL}$ physiological $\mathrm{NaCl}$ (Merck ${ }^{\circledR}$ ) $0.85 \%$. The suspension was homogenized and serially diluted. Then $0.1 \mathrm{~mL}$ of the suspension from each dilution was inoculated into a Petri dish containing medium Tryptic Soy Agar (TSA) (Merck $\left.{ }^{\circledR}\right)$ using a spread plate method, then incubated at $27^{\circ} \mathrm{C}$ for 1 $3 \times 24$ hours. Growing isolates were observed for the colony morphology.

Bacterial colonies that grow are purified on TSA plates using a quadrant streak plate method. Purified endophytic bacterial isolates were then stained through Gram staining. Gram staining is done by referring to Cappucino \& Sherman (2014)
[12], using the Gram (Merck®) staining kit.

\section{Screening of endophytic anti-phytopathogens ac- tivity}

All isolated endophytic bacterial isolates were screened to determine its anti-phytopathogens activity against $R$. solanacearum, $X$. campestris, $F$. oxysporum, and $S$. rolfsii. $R$. solanacearum and $X$. campestris were from culture collection of Microbiology Laboratory, Faculty of Agriculture, Andalas University, Padang, Indonesia. F. oxysporum and S. rolfsii were from culture collection of Phytopathology Laboratory, Faculty of Agriculture, Andalas University, Padang, Indonesia. Screening of anti-phytopathogen activity was carried out disk diffusion method which refers to Melliawati et al. (2006) [13]. Positive control used 15 ppm of chloramphenicol for bacteria, while positive control of fungus used 15 ppm of ketoconazole.

\section{Identification of endophytic bacteria through $16 S$ rRNA Analysis}

The assay was done by planting Pure culture of endophytic bacteria was inoculated into a test tube containing $4 \mathrm{~mL}$ of Tryptic Soy Broth medium (Merck ${ }^{\circledR}$ ) and incubated using a shaker for 24 hours. The results of the culture were taken as much as $3 \mathrm{~mL}$, then centrifuged at a speed of 13,000 rpm, for 5 minutes. Pellets are taken to extract the genome DNA using the Wizard ${ }^{\circledR}$ Genomic DNA purification kit (Promega Corp.) following the manufacturer's instructions. DNA amplification was carried out by preparing the mix reagent mixture for PCR as follows (KAPA Taq

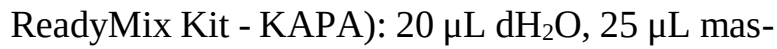
ter mix PCR, $2 \mu \mathrm{L}$ primer 9F (20 pmol) (5'-GAG TTT GAT CCT GGC TCA G-3'), $2 \mu$ Primer 1541R (20 pmol) (5'-AAG GAG GTG ATC CAG CC-3'), and $1 \mu \mathrm{L}$ DNA Template with a total volume of $50 \mu \mathrm{L}$. PCR amplification was carried out as many as 30 cycles with the following programs: preheat at $96^{\circ} \mathrm{C}$ for 5 minutes, denaturation at $96^{\circ} \mathrm{C}$ for 30 seconds, annealing at $55^{\circ} \mathrm{C}$ for $30 \mathrm{sec}-$ onds, elongation at $72^{\circ} \mathrm{C}$ for 1 minute, extension at $72^{\circ} \mathrm{C}$ for 7 minutes. PCR results were electrophoresed in $1 \%$ agarose gel using $1 \times$ TAE buffer then visualized using gel illuminator. Agarose gel is photographed as documentation. The PCR results are cleaned using the SV Gel and PCR CleanUp System (Promega) Wizard.

The purified DNA extract was sent to First 
Table 1. Cell numbers of isolated endophytic bacteria

\begin{tabular}{lllc}
\hline No. & Plant species & Obtained isolate & Cell numbers (CFU/g leaf) \\
\hline 1. & A. altilis (Parkinson) Fosberg & 4 & $4.0 \times 10^{2}$ \\
2. & Ann. muricata L. & 1 & $1.0 \times 10^{2}$ \\
3. & B. javanica (L.) Merr. & 1 & $1.0 \times 10^{2}$ \\
4. & C. aurantifolia Swingle & 4 & $7.0 \times 10^{2}$ \\
5. & Che. speciosus (J. Konig) C. Specht & 1 & $2.0 \times 10^{2}$ \\
6. & D. metel L. & 1 & Cannot be isolated \\
7. & M. zapota (L.) P. Royen & 3 & $1.0 \times 10^{2}$ \\
8. & Mor. citrifolia L. & & $5.0 \times 10^{2}$ \\
9. & S. cumini (L.) Skeels. & 1 & Cannot be isolated \\
10. & T. crispa (L.) Miers & & $1.0 \times 10^{2}$ \\
\hline
\end{tabular}

Base Malaysia for sequencing of the base arrangement. Sequences are checked and edited using the BioEdit program. The similarity was analyzed using the Basic Local Alignment Tool (BLAST) at the National Center for Biotechnology Information (http://www.ncbi.nlm.nih.gov). The identified strains were then registered to obtain an accession number; then phylogenetic analysis was carried out using ClustalW2 phylogenetic tree at http://ebi.ac.uk.

\section{Results and Discussion}

Isolation and purification of endophytic bacteria

A total of Sixteen isolates of endophytic bacteria were obtained from 8 of 10 plants species in this study. These isolates were obtained from eight plant species, but the bacteria in the other two plants (D. metel L. and S. cumini (L.) Skeels.) were not isolated. The variety of isolates obtained ranged from one to four isolates for each plant (Table 1). The results of this study are not much different from the results previously reported, ranging from one to six isolates per plant $[13,14,15]$. No endophytic bacteria were found in the plants of D. metel L. and S. cumini (L.) Skeels. Presumably, when the isolation was carried out, the plant is dominated by obligate endophytic bacteria, so it cannot be cultured. Hardoim et al. (2008) [16] explained that many endophytic bacteria were obligate endophytes.

Based on the results of Gram staining, 12 isolates were Gram-positive and 4 isolates were Gram-negative (Table 2). It can be concluded that in this study Gram-positive bacteria were a group of dominant bacteria. Gayathri et al. (2010) [17] and Anjum \& Chandra (2015) [18] also obtained Gram-positive bacteria as endophytic bacteria in their study.

\section{Anti-phytopathogens activity of endophytic bac- teria}

In general, isolated endophytic bacteria have anti-phytopathogens activity. Eight isolates had anti-phytopathogens activity against R. solanacearum; seven isolates had anti-phytopathogens activity against $X$. campestris, nine isolates had antiphytopathogens activity against $F$. oxysporum, and five isolates had anti-phytopathogens activity against $S$. rolfsii (Table 2). The endophytic bacteria that have been isolated have low anti-phytopathogens activity against phytopathogenic bacteria $(2 \mathrm{~mm})$ compared to anti-phytopathogens activity against phytopathogenic fungi $(8 \mathrm{~mm}-17$ $\mathrm{mm})$. Based on the criteria by Davis and Stout (1971) [19] anti-phytopathogens activity against phytopathogenic bacteria in this study was weak (inhibitory zone was $<5 \mathrm{~mm}$ ), whereas anti-phytopathogens activity against phytopathogenic fungi was moderate (inhibitory zone was $5-10$ $\mathrm{mm}$ ) and strong (inhibitory zone was $10-20 \mathrm{~mm}$ ).

The results obtained indicate that the endophytic bacteria obtained have the potential to be developed as a biocontrol agent or as a biopesticide producer against phytopathogenic fungi. Endophytic bacteria can produce lysis enzymes against compounds such as chitin, protein [20], cellulose, and hemicellulose [21]. These enzymes can result in direct suppression of the activity of phytopathogenic microbes [21].

The ability of endophytic bacteria to produce anti-phytopathogens compounds was very beneficial for host plants, because host plants can be used against phytopathogen [22]. According to Haas \& Defago (2005) [23], this was caused by 
Table 2. Characteristics of isolates and anti-phytopathogens activity against test microbes

\begin{tabular}{lllllll}
\multirow{2}{*}{ No. } & \multirow{2}{*}{ Isolate } & \multirow{2}{*}{ Gram staining } & \multicolumn{4}{c}{ Inhibitory zone $(\mathrm{mm})$} \\
\cline { 4 - 7 } & & R. solanacearum & X. campestris & F. oxysporum & S. rolfsii \\
\hline 1. & AAF1 & Negative & 2 & 0 & 8 & 0 \\
2. & AAF2 & Positive & 2 & 2 & 17 & 16 \\
3. & AAF3 & Negative & 2 & 0 & 11 & 0 \\
4. & AAF4 & Negative & 2 & 0 & 0 & 0 \\
5. & AMF1 & Positive & 0 & 0 & 0 & 0 \\
6. & BJF1 & Positive & 2 & 0 & 14 & 0 \\
7. & CAF1 & Positive & 2 & 0 & 0 & 0 \\
8. & CAF2 & Negative & 2 & 2 & 0 & 0 \\
9. & CAF3 & Positive & 0 & 2 & 16 & 15 \\
10. & CAF4 & Positive & 0 & 0 & 12 & 12 \\
11. & CSF1 & Positive & 0 & 2 & 13 & 0 \\
12. & MZF1 & Positive & 0 & 2 & 0 & 0 \\
13. & MCF1 & Positive & 0 & 2 & 15 & 14 \\
14. & MCF2 & Positive & 2 & 0 & 0 & 0 \\
15. & MCF3 & Positive & 0 & 2 & 10 & 13 \\
16. & TCF1 & Positive & 0 & 20 & 26 & 0 \\
17. & Positive & Control & 21 & & & 24 \\
\hline
\end{tabular}

active plants responding to various environmental stimuli and can also respond to various chemical compounds stimulated by microbes. Both by soil microbes, as well as microbes associated with plants.

In general, endophytic bacteria have an excellent ability to inhibit phytopathogenic fungi, when compared to phytopathogenic bacteria. According to Bloemberg \& Lugtenberg (2001) [24], This ability was caused by the ability of endophytic bacteria to produce diffuse and volatile antifungal compounds. Endophytic bacteria could mediate de novo antimicrobial synthesis and new antifungal secondary metabolites, which have been accepted as potential fungicides to prevent the spread of phytopathogens [25].

To determine the anti-phytopathogens activity, the disc diffusion method was applied. This method was one of the easy-to-use methods for the selection of biocontrol bacterial agents and has proven to be the right strategy for this experimental system [26]. This method was used to determine whether the isolates used can produce compounds that can interfere with the target microbial life cycle [27]. According to Elad \& Chet (1995) [28], The disadvantage of this method was that researchers sometimes inadvertently ignore endophytic bacteria that do not exhibit anti-phytopathogens activity, and this allows the discovery of antagonists in controlling phytopathogens through other mechanisms, such as inactivation of virulence factors [29].

\section{Identification of endophytic bacterial isolates that have anti-phytopathogens activity}

Based on the results of $16 \mathrm{~S}$ rDNA sequence analysis, 14 isolates were identified into nine different species with similarity ranged from $94-99 \%$ to the nearest strain (Table 3). The isolates which have similarities $>97 \%$ can be identified as the same species, however, the similarity $<97 \%$ is identified as the same genus [30]. All identified isolates are new strains, and each is registered in the National Center for Biotechnology Information (NCBI) database with accession numbers KY806221-KY806234.

Anti-phytopathogens activity test results (Table 2) shows that strains from the isolated Bacillus genus have diverse anti-phytopathogens activities. $B$. indicus BJF1 has anti-phytopathogens activity against $R$. solanacearum and $F$. oxysporum; $B$. indicus TCF1 only has anti-phytopathogens activity against $X$. campestris; and $B$. indicus MCF2 has anti-phytopathogens activity against $R$. solanacearum and $X$. campestris. $B$. indicus was first discovered by Suresh et al. (2004) [31] in the waters of West Bengal, India, and these bacteria were resistant to arsenic. Hong et al. (2008) [32] report- 
Table 2. Strains of endophytic bacteria based on the results of molecular identification through 16S rDNA analysis

\begin{tabular}{|c|c|c|c|c|}
\hline No. & Isolate & $\begin{array}{l}\text { Accession number as- } \\
\text { signed }\end{array}$ & $\begin{array}{l}\text { Closest type strain } \\
\text { (accession number) }\end{array}$ & $\begin{array}{l}\text { Similarity } \\
(\%)\end{array}$ \\
\hline 1. & AAF1 & KY806234 & Pseudomonas psychrotolerans AP9-27B (KM891562) & 99 \\
\hline 2. & AAF2 & KY806226 & Bacillus subtilis SSCT68 (AB210968) & 99 \\
\hline 3. & AAF3 & KY806233 & P. oryzihabitans AF31 (LC015573) & 99 \\
\hline 4. & AAF4 & KY806232 & Pantoea stewartii M073 & 99 \\
\hline 5. & BJF1 & KY806221 & B. indicus (KF791344) & 99 \\
\hline 6. & CAF1 & KY806225 & B. cereus RNS_01 (KT380683) & 94 \\
\hline 7. & CAF2 & KY806231 & Pantoea agglomerans ZFJ-15 (EU931554) & 99 \\
\hline 8. & CAF3 & KY806228 & B. subtilis 55C1-1 (JN366797) & 99 \\
\hline 9. & CAF4 & KY806224 & B. pumilus FI39 (KT318787) & 99 \\
\hline 10. & CSF1 & KY806230 & Kocuria kristinae LCT (KR230389) & 99 \\
\hline 11. & MCF1 & KY806227 & B. subtilis subsp. inaquosorum MER_77 (KT719652) & 99 \\
\hline 12. & MCF2 & KY806223 & B. indicus WJB 131 (KU877665) & 99 \\
\hline 13. & MCF3 & KY806229 & B. subtilis SR41 (KY203664) & 99 \\
\hline 14. & TCF1 & KY806222 & B. indicus WJB 131 (KU877665) & 99 \\
\hline
\end{tabular}

ed $B$. indicus to be safely used as a prebiotic. However, there have been no reports of these bacteria as endophytes and their ability to produce antiphytopathogens compounds. This study was first reported that the bacterium as endophytic and has anti-phytopathogens activity. Further research was needed to determine the potential of these strains as biopesticide producers.

$B$. subtilis belongs to Bacillus genus which has the most strains in this study (four strains). Three strains had anti-phytopathogens activity against phytopathogenic bacteria and fungi, namely $B$. subtilis CAF3, B. subtilis MCF1, and B. subtilis AAF2, whereas one strain only had antibacterial activity, namely $B$. subtilis MCF3 (Table 2). B. subtilis was generally found in soil, water, and associated with plants [33]. Several strains of $B$. subtilis have been reported as endophytes and have the ability to inhibit soil-borne phytopathogens [34], such as $X$. campestris [35], R. solanacearum [36], F. oxysporum [37, 38] and S. rolfsii [39]. B. subtilis was reported to have the ability to produce antimicrobials, such as antimicrobial lipopeptides [40], so that these bacteria have considerable antimicrobial activity.

Strains from other Bacillus genera also have anti-phytopathogens activity, such as Bacillus sp. CAF1 against $R$. solanacearum; and $B$. pumilus CAF4 against $F$. oxysporum and $S$. rolfsii. Sturz et al. (2005) [41] reported that B. pumilus isolated from endorhiza and potato exorhiza could have anti-phytopathogens activity against $F$. oxyspo- rum. de Melo et al. (2009) [10] also reported that these bacteria also had anti-phytopathogens activity against $S$. rolfsii. Therefore, it can be concluded that Bacillus was a genus of endophytic bacteria that has the potential to be developed as a biocontrol agent because it can inhibit the growth of bacteria and fungi. Forchetti et al. (2007) [42] mentions that strains of the Bacillus have the advantage of being developed as biopesticides compared to other bacteria. Strains from this genus are easily to be cultured and stored; can be applied as spores, or inoculants to seeds, or bioactive compounds produced; shows a protective effect on various pathogenic microbes and improve plant growth.

$K$. christinae CSF1 has anti-phytopathogens activity against $X$. campestris and $F$. oxysporum. This bacterium is also known as Micrococcus kristinae. This bacterium was first isolated by Kovacs et al. (1999) [43] from the roots of Typha angustifolia. These bacteria are found as endophytes in some plants, such as Solanum tuberosum [41], Carica papaya [44], Panicum virgatum [45], and Durio spp. [46]. K. kristinae can inhibit the growth of $F$. oxysporum [41], dissolve phosphate [46], and have pectinase enzyme activity [44].

Strains of the isolated Pantoea genus in this study only had antibacterial activity. Pan. agglomerans CAF2 have anti-phytopathogens activity against $R$. solanacearum and $X$. campestris, while Pan. stewartii AAF4 only has anti-phytopathogens activity against $R$. solanacearum. Pantoea 


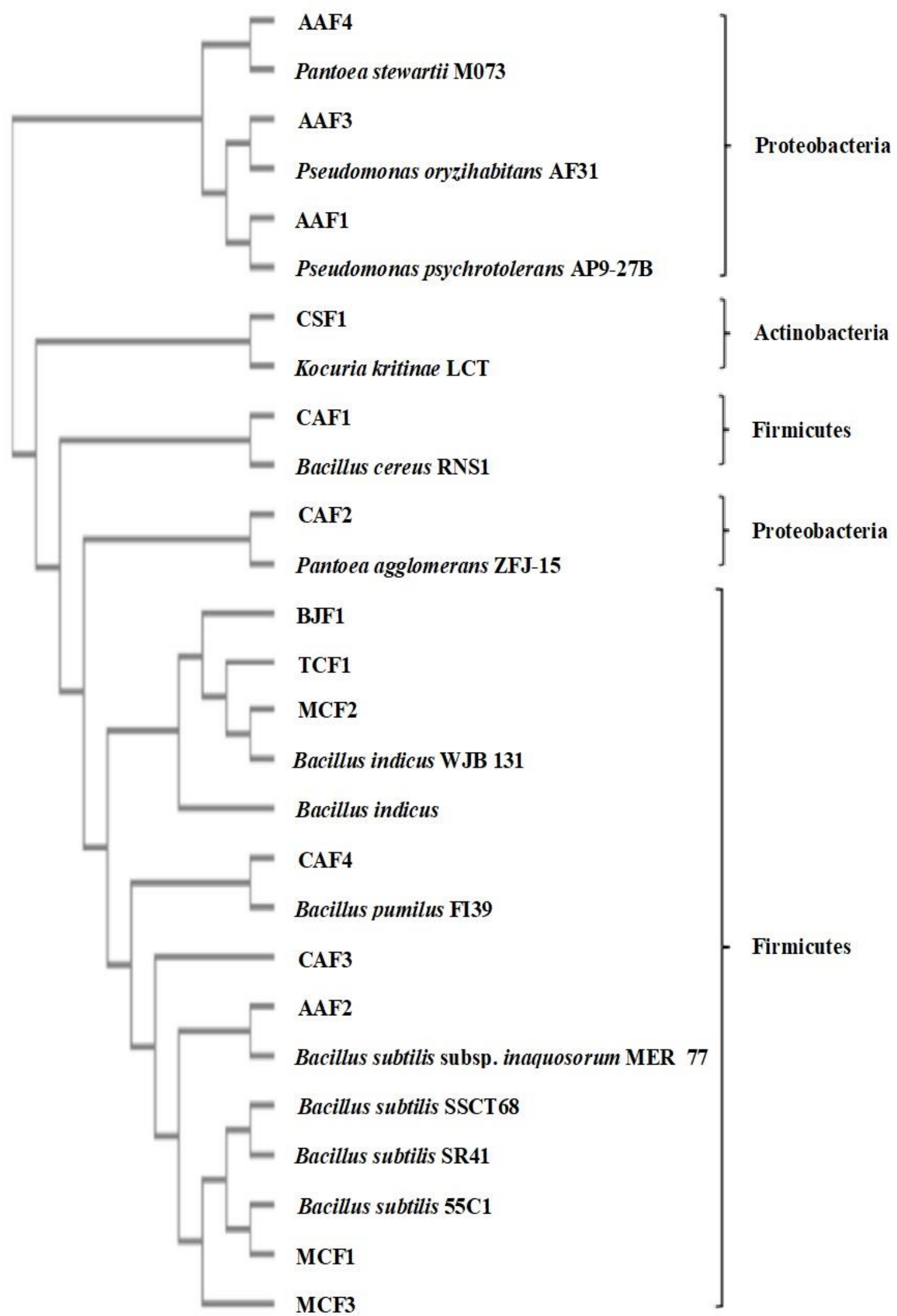

Figure 1. Phylogenetic tree strains of endophytic bacteria that have anti-phytopathogens activity 
was found in Citrus spp. [11], Arachis hypogea L. [47], Zea mays L. [48], and in several other plants that have been studied. Pantoea spp. reported to produce IAA [47], siderofor [49], and have the ability to fix nitrogen [48]. This bacterium does not have antifungal activity against phytopathogenic fungi [50]. Both strains of Pantoea identified in this study have opportunistic properties. Pan. agglomerans are opportunistic to cotton plants [51], however, Pan. stewartii was opportunistic towards maize plants [52, 53].

P. psychrotolerans AAF1 and P. oryzihabitans AAF3 have anti-phytopathogens activity against $R$. solanacearum and $F$. oxysporum. Lamessa \& Zeller (2007) [54] reported that Pseudomonas was a potential genus that can control $\mathrm{R}$. solanacearum. Chaiharn et al. (2009) [55] and Munif et al. (2012) [56] adding this genus can also inhibit the growth of F. oxysporum. Pseudomonas was capable of producing siderophore [57], and these compounds can inhibit the growth of phytopathogenic microbes [58].

Based on the results obtained it can be concluded that endophytic bacteria that are identified are quite diverse and have various anti-phytopathogens activities. Host plants can be a limiting ability. This can be seen from the anti-phytopathogens ability of $B$. subtilis isolated from different plants having different anti-phytopathogens activity against phytopathogens. B. subtilis is a fairly dominant species found in this study. B. subtilis was reported by Jacobsen et al. (2004) [59] can produce antimicrobial peptides and contribute to leaf and root disease. Also, the bacteria also produce lipopeptide, which is an amphiphilic compound with surfactant activity [60]. Bacillus has secondary metabolite products that are attractive with a broad antimicrobial spectrum and very diverse structures [61].

The Bacillus is the most common genus found as endophytes. This is supported by the results of several studies which claim the Bacillus is dominant in some plants, such as Jacarandra decurrens [62], Panax spp. [63, 64], Manihot esculenta [10], Solanum lycopersicum [56], Polygonum cuspidatum [65], and Musa spp. [66]. Bacillus is known as a cosmopolitan genus and has high survival ability. This can be caused by the presence of endospores. Moat et al. (2002) [67] stated that endospores contained in cells have a role in protecting organisms against unfavorable environmental conditions. This leads to organisms that have them will be able to survive and maintain their existence.

\section{Phylogenetic endophytic bacterial isolates that have anti-phytopathogens activity}

The results of phylogenetic analysis of endophytic bacterial strains that have anti-phytopathogens activity using UPGMA (Figure 1) show strains of endophytic bacteria that have anti-phytopathogens activity grouped into three phyla. Firmicutes are dominant phylum (64.3\%), followed by Proteobacteria (28.6\%), and Actinobacteria (7.1\%). The three phyla are commonly found as endophytes in various plants $[68,69]$. Some results of the study report that phylum Firmicutes is the dominant phylum [66,70,71], followed by Proteobacteria and Actinobacteria, respectively [66, 71].

Phylogenetic tree show that the strains obtained were grouped into two groups originating from different ancestors. The first group was Pan. stewartii AAF4, $P$. oryzihabitans AAF3, and $P$. psychrotolerans AAF1, while the second group was K. kristinae CSF1, Bacillus sp. CAF1, Pan. agglomerans $\mathrm{CAF} 2, B$. indicus BJF1, $B$. indicus TCF1, B. indicus MCF2, B. pumilus CAF4, B. subtilis CAF3, $B$. subtilis AAF2, $B$. subtilis MCF1, and B. subtilis MCF3. In general, the strains that were owned have a close relationship with strains that have similarities with them, only $B$. subtilis AAF2 and B. subtilis MCF1 strains were different. $B$. subtilis AAF2 has similarities with $B$. subtilis SSCT68, but has a kinship with $B$. subtilis subsp. inaquosorum MER_77, B. subtilis MCF1 has similarities with $B$. subtilis subsp. inaquosorum MER_77, but has a kinship with B. subtilis 55CI-1. Triana (2005) [87] found that different species have close molecular relationships, namely Photorhizobium thomsonianum BTAi1 with Blastobacter denitrificans.

\section{Conclusion}

Sixteen isolates of endophytic bacteria from eight species of medicinal plants were obtained. Fourteen isolates had anti-phytopathogens activity (eight isolates against $R$. solanacearum, seven isolates against $X$. campestris, nine isolates against $F$. oxysporum, and five isolates against $S$. rolfsii. Identification of the fourteen isolates showed that Firmicutes were dominant phylum (64.3\%), followed by Proteobacteria (28.6\%) and Actinobac- 
teria (7.1\%). Phylum Firmicutes consist of $B$. indicus (BJF1, TCF1, and MCF2), B. pumilus (CAF4), Bacillus sp. (CAF1), B. subtilis (AAF2, MCF1, CAF3, and MCF3); phylum Proteobacteria consists of Pan. agglomerans (CAF2), Pan. stewartii (AAF4), P. oryzihabitans (AAF3), and P. psychrotolerans (AAF1); and phylum Actinobacteria consists of K. kristinae (CSF1).

\section{Acknowledgment}

The author would like to thank to the LPDP for Disertasi Program Scholarship which is awarded to Syukria Ikhsan Zam, so that this research could be accomplished.

\section{References}

1. Strobel G, Daisy B, Castillo U, Herper J (2004) Natural products from endophytic microorganism. Journal of Natural Products 67 (2): 257 - 268. doi: 10.1021/np030397v.

2. Berg G, Elberl L, Hartmann A (2005) The rhizosphere as a reservoir for opportunistic human pathogenic bacteria. Environmental Microbiology 7 (11): 1673 - 1685. doi: 10.1111/j.1462-2920.2005.00891.x.

3. Castillo UF, Strobel GA, Ford EJF et al. (2002) Munumbicins, wide-spectrum antibiotics produced by Streptomyces NRRL 30562, endophytic on Kennedia nigriscans. Microbiology 148 (Pt 9): 2675 - 2685. doi: 10.1099/00221287-148-9-2675.

4. Berg G, Hallmann J (2006) Control of plant pathogenic fungi with bacterial endophytes. In: Schulz B, Boyle C, Sieber TN, eds. Soil Biology 9: Microbial root endophytes. Berlin, Springer. pp $63-67$.

5. Raudales RE, Gardener BBM (2008) Microbial biopesticides for the control of plant diseases in organic farming. Fact Sheet Agriculture and Natural Resources. Ohio, The Ohio State University.

6. Genin S, Boucher C (2004) Lessons learned from the genome analysis of Ralstonia solanacearum. Annual Review of Phytopathology 42: 107 - 134. doi: 10.1146/annurev.phyto.42.0112 04.104301.

7. Jacobs JM, Pesce C, Lefeuvre P, Koebnik R (2015) Comparative genomics of cannabis pathogen reveals insight into the evolution of pathogenicity in Xanthomonas. Frontiers in Plant Science 6: 431. doi: 10.3389/fpIs.2015.00431.

8. Ortoneda M, Guarro J, Marta PM, Caracuel ZM, Roncero IG, Mayayo E, Antonio DP (2004) Fusarium oxysporum as a multihost model for genetic dissection of fungal virulence in plant and mammals. Infection and Immunity 72 (3): 1760 - 1766. doi: 10.1128/IAI.72.3.1760-1766.2004

9. Kator L, Hosea ZY, Oche OD (2015) Sclerotium rolfsii: Causative organism of southern blight, stem root, white mold and sclerotia root disease. Annuals of Biological Research 6 (11):
$78-89$.

10. de Melo FMP, Fiore MF, de Morales LAB et al. (2009) Antifungal compound produced by the cassava endophyte Bacillus pumilus MAIIIM4A. Scientia Agricola 66 (5): 583 - 592. doi: 10.1590/S0103-90162009000500002.

11. Araujo WL, Maccheroni WJr, Aguilar-Vildoso CI et al. (2001) Variability and interaction between endophytic bacteria and fungi isolated from leaf tissues of Citrus rootstock. Canadian Journal of Microbiology 47 (3): 229 - 236. doi: 10.1139/cjm47-3-229.

12. Capucino JG, Sherman N (2014) Microbiology: A laboratory manual. 10th Edition. Boston, Pearson Education.

13. Melliawati R, Widyaningrum DN, Djohan AC, Sukiman H (2006) Study on endophytic bacteria for bioactive compound production use as plant protection agent. Biodiversitas Journal of Biological Diversity 7 (3): 221 - 224.

14. Zinniel DK, Lambrecth $P$, Harris NB et al. (2002) Isolation and characterization of endophytic colonizing bacteria from agronomic crops and prairie plants. Applied Environmental Microbioliogy 68 (5): 2198-2208. doi: 10.1128/AEM.68.5.21982208.2002

15. Yuliar, Suciatmih, Supriyati D, Rahmansyah M (2013) Biodiversity of endophytic bacteria and their antagonistic activity to Rhizoctonia solani and Fusarium oxysporum. Global Journal of Biology, Agriculture \& Health Sciences 2 (4): 111 - 118.

16. Hardoim PR, van Overbeek LS, van Elsas JD (2008) Properties of bacterial endophytes and their proposed role in plant growth. Trend in Microbiology 16 (10): 463 - 471. doi: 10.1016/j.tim.2008.07.008.

17. Gayathri S, Saravanan D, Radhakrisnan M et al. (2010) Bioprospecting potential of fast growing endophytic bacteria from leaves of mangrove and salt-marsh plant species. Indian Journal of Biotechnology 9 (4): 397 - 402.

18. Anjum N, Chandra R (2015) Endophytic bacteria optimization of isolation procedure from various medicinal plants and their preliminary characterization. Asian Journal Pharmaceutical and Clinical Research 8 (4): 233 - 238.

19. Davis WW, Stout TR (1971) Disc plate methods of microbiological antibiotic assay. Applied Microbiology 22 (4): 659 665.

20. Huang CJ, Wang TK, Chung SC, Chen CY (2005) Identification of an antifungal chitinase from a potential biocontrol agent Bacillus cereus 28-9. Journal of Biochemistry and Molecular Biology 38 (1): 82 - 88. doi: 10.5483/BMBRep.2005.38.1.082

21. Kobayashi DY, Reedy RM, Bick JA, Oudemans PV (2002) Characterization of chitinase gene from Stenotrophomonas maltophila strain 34 SI and its involvement in biological control. Applied and Environmental Microbiology 68 (3): 1047 1054. doi: 10.1128/AEM.68.3.1047-1054.2002.

22. Guo B, Wang Y, Sun X, Tang K (2008) Bioactive natural products from endophytes: A review. Applied Biochemistry and 
Microbiology 44 (2): 136 - 142. doi: 10.1134/S00036838080 20026.

23. Haas D, Defago G (2005) Biological control of soil-borne pathogens by fluorescent pseudomonads. Nature Reviews Microbiology 3 (4): 307 - 319. doi: 10.1038/nrmicro1129.

24. Bloemberg GV, Lugtenberg BJJ (2001) Molecular basis of plant growth promotion and biocontrol by rhizobacteria. Current Opinion in Plant Biology 4 (4): 343 - 350. doi: 10.1016/ S1369-5266(00)00183-7.

25. Yang C, Zhang X, Shi G (2011) Isolation and identification of endophytic bacterium W4 against tomato Botrytis cinereal and antagonistic activity stability. African Journal of Microbiology Research 5 (2): 131 - 136. doi: 10.5897/AJMR10.815.

26. Pliego C, Ramos C, de Vicente A, Cazorla FM (2011) Screening for candidate bacterial biocontrol agents against soilborne fungal plant pathogens. Plant Soil 340 (1 - 2): 505 - 520. doi: 10.1007/s11104-010-0615-8.

27. Burkhead KD, Schisler DA, Slininger PJ (1995) Bioautography shows antibiotic to fungal dry rot of potatoes. Soil Biology and Biochemistry 27 (12): 1611 - 1616. doi: 10.1016/0038 -0717(95)00095-V.

28. Elad Y, Chet I (1995) Practical approaches for biocontrol implementation. In: Reuveni R, ed. Novel approaches to integrated pest management. Boca Raton, Lewis Publisher CRC Press. pp $323-338$.

29. Fedi S, Tola E, Moenne-Loccoz Y et al. (1997) Evidence for signalling between the phytopathogenic fungus Phytium ultimum and Pseudomonas flourescens F113 - P. ultimum represses the expression of gene in $P$. flourescens F113, resulting in altered ecological fitness. Applied and Environmental Microbiology 63 (11): 4261 - 4266.

30. Stackenbrandt E, Goebel BM (1994) Taxonomic note: a place for DNA-DNA reassociation and 16S rRNA sequence analysis in the present species definition in bacteriology. International Journal of Systematic 44 (4). doi: 10.1099/00207713-44-4846.

31. Suresh K, Prabagaran SR, Sengupta S, Shivaji S (2004) Bacillus indicus sp. nov. an arsenic-resistant bacterium isolated from an aquifer in West Bengal, India. International Journal of Systematic and Evolutionary Microbiology 54: 1369 - 1375. doi: 10.1099/ijs.0.03047-0.

32. Hong HA, Huang JM, Khaneja R et al. (2008) The safety of Bacillus subtilis and Bacillus indicus as food probiotics. Journal of Applied Microbiology 105 (2): 510 - 520. doi: 10.1111/j.1365-2672.2008.03773.x.

33. Chun J, Sook KB (2000) Phylogenetic analysis of Bacillus subtilis and related taxa based on partial gyrA gene sequence. Antonie van Leeuwenhoek 78 (2): 123 - 127. doi: 10.1023/A:1026555830014.

34. Ongena M, Duby J, Jourdan E et al. (2005) Bacillus subtilis M4 decrease plant susceptibility towards fungal pathogens by increasing host resistance associated with differential gene expression. Applied Microbiology and Biotechnology 67 (5): 692 - 698. doi: 10.1007/s00253-004-1741-0.

35. Issazadeh K, Rad SK, Zarrabi S, Rahimibashar MR (2012) Antagonism of Bacillus species against Xanthomonas campestris pv. Campestris and Pectobacterium corotovorum subsp. corotovorum. African Journal of Microbiology Research 6 (7): 1615 - 1620. doi: 10.5897/AJMR12.075.

36. Ji X, Lu G, Gai Y et al. (2008) Biological control against bacterial wilt and colonization of mulberry by an endophytic $\mathrm{Ba}$ cillus subtilis strain. FEMS Microbiology Ecology 65 (3): 565 - 573. doi: 10.1111/j.1574-6941.2008.00543.x.

37. Liu B, Huang L, Buchenauer H, Kang Z (2010) Isolation and partial characterization of an antifungal protein from the endophytic Bacillus subtilis strain EDR4. Pesticide Biochemistry and Physiology 98 (2): 305 - 311. doi: 10.1016/j.pestbp.2010.07.001.

38. Souza A, Cruz JC, Sousa NR et al. (2014) Endophytic bacteria from banana cultivars and their antifungal activity. Genetics and Molecular Research 13 (4): 8661 - 8670. doi: 10.4238/2014.October.27.6.

39. Thasana N, Prapagdee B, Ramgkadilok N et al. (2010) Bacillus subtilis SSE4 produces subtulene A, a new lipopeptide antibiotic possessing an unusual $\mathrm{C} 15$ unsaturated $\beta$-amino acid. FEBS Letters 584 (14): 3209 - 3214. doi: 10.1016/j.febslet.2010.06.005.

40. Akpa E, Jacques P, Wathelet B et al. (2001) Influence of culture condition on lipopeptide production by Bacillus subtilis. Applied Biochemistry and Biotechnology 91: 551 - 561. doi: 10.1385/АВAB:91-93:1-9:551.

41. Sturz AV, Peters RD, Carter MR et al. (2005) Variation in antibiosis ability, against potato pathogens, of bacterial communities recovered from the endo- and exoroots of potato crops produced under conventional versus minimum tillage systems. Canadian Journal of Microbiology 51 (8): 643 - 654. doi: 10.1139/W05-041.

42. Forchetti G, Masciarelli O, Alemano S et al. (2007) Endophytic bacteria in sunflower (Helianthus annus L.) isolation, characterization and production of jasmonates and abcisic acid in culture medium. Applied Microbiology and Biotechnology 76 (5): 1145 - 1152. doi: 10.1007/s00253-007-1077-7.

43. Kovacs G, Burghardt J, Pradella S et al. (1999) Kocuria palustris sp. nov. and Kocuria rhixophila sp. nov., isolated from rhizoplane of the narrow-leaved cattail (Typha angustifolia). International Journal of Systematic Bacteriology 49 (1): 167 173.

44. Krishnan P, Bhat R, Kush A, Ravikumar P (2012) Isolation and functional characterization of bacterial endophytes from Carica papaya fruits. Journal of Applied Microbiology 113 (2): 308 - 317. doi: 10.1111/j.1365-2672.2012.05340.x.

45. Xia Y, Greissworth E, Mucci C et al. (2013) Characterization 
of culturable bacterial endophytes of switchgrass (Panicum virgatum $\mathrm{L}$.) and their capacity to influence plant growth. GCB Bioenergy 5 (6): 674 - 682. doi: $10.1111 / \mathrm{j} \cdot 1757-$ 1707.2012.01208.x.

46. Suhandono S, Utari IB (2014) Isolation and molecular identification of endophytic bacteria from the arils of durian (Durio zibethinus Murr.) var. Matahari. Microbiology Indonesia 8 (4): 161 - 169. doi: 10.5454/mi.8.4.3.

47. Wang S, Wang W, Jin Z et al. (2013) Screening and diversity of plant growth promoting endophytic bacteria from peanut. African Journal of Microbiology Research 7 (10): 875 - 884. doi: 10.5897/AJMR12.1500.

48. Montanez A, Abreu C, Gill PR, Hardarson G, Sicardi M (2009) Biological nitrogen fixation in maize (Zea mays L.) by $15 \mathrm{~N}$ isotope-dilution and identification of associated culturable diazotrophs. Biology and Fertility of Soils 45 (3): 253 - 263. doi: 10.1007/s00374-008-0322-2.

49. Becerra-Castro C, Kidd PS, Prieto-Fernandez A, Weyens N et al. (2011) Endophytic and rhizoplane bacteria associated with Cytisus striatus growing on hexachlorocyclohexane-contaminated soil: Isolation and caracterization. Plant Soil. 340: 413433. doi: 10.1007/s11104-010-0613-X.

50. Burch G, Sarathchandra U (2006) Activities and survival of endophytic bacteria in white clover (Trifolium repens L.). Canadian Journal of Microbiologi 52 (9): 848 - 856. doi: 10.1139/w06-039.

51. Medrano EG, Bel AA (2007) Role of Pantoea agglomerans in opportunistic bacterial seed and boll rot of cotton (Gossypium hirsutum) grown in field. Journal of Applied Microbiology 102 (1): 134 - 143. doi: 10.1111/j.1365-2672.2006.03055.x.

52. Roper MC (2011) Pantoea stewartii subsp. stewartii: Lessons learned from xylem-dwelling pathogen of sweet corn. Molecular Plant Pathology 12 (7): 628 - 637. doi: 10.1111/j.13643703.2010.00698.x.

53. Correa VR, Majerczak DR, Ammar E et al. (2012) The bacterium Pantoea stewartii uses two different type III secretion systems to colonize its plant host and insect vector. Applied and Environmental Microbiology 78 (17): 6327 - 6336. doi: 10.1128/AEM.00892-12.

54. Lamessa G, Zeller W (2007) Screening rhizobacteria for biological control of Ralstonia solanacearum in Ethiopia. Biological Control 49 (3): 336 - 344. doi: 10.1016/j.biocontrol.2007.05.014

55. Chaiharn M, Chunhaleuchanon S, Lumyong S (2009) Screening siderophore producing bacteria as potential biological control agent for fungal rice pathogens in Thailand. World Journal of Microbiology and Biotechnology 25 (11): 1919 - 1928. doi: 10.1007/s11274-009-0090-7.

56. Munif A, Hallman J, Sikora R (2012) Isolation of endophytic bacteria from tomato and their biocontrol activities against fungal diseases. Microbiology Indonesia 6 (4): 148 - 156. doi: 10.5454/mi.6.4.2

57. Tian F, Dang YQ, Zhu H et al. (2009) Genetic diversity of siderophore-producing bacteria of tobacco rhizosphere. Brazilian Journal of Microbiology 40 (2): 276 - 284. doi: 10.1590/S1517-838220090002000013.

58. Duffy BK, Defago G (1999) Environmental factors modulating antibiotic and siderophore biosynthesis by Pseudomonas flourescens biocontrol strains. Applied and Environmental Microbiology 65 (6): 2429 - 2438

59. Jacobsen BJ, Zidaek NK, Larson BJ (2004) The role of Bacillus-based biological control agents in integrated pest management systems: Plant diseases. Phytopathology 94 (11): 1272 1275. doi: 10.1094/PHYTO.2004.94.11.1272.

60. Zuber P, Nakano MM, Marahiel MA (1993) Peptide antibiotic. In: Sonenshein AL, Hoch J, Losick R, eds. Bacillus subtilis and other Gram-positive bacteria. Washington, American Society for Microbiology. pp 897 - 916.

61. Moyne AL, Cleveland TE, Tuzun S (2004) Molecular characterization and analysis of the operon encoding the antifungal lipopeptide bacillomycin. FEMS Microbiologi Letters 234 (1): 43 - 52. doi: 10.1111/j.1574-6968.2004.tb09511.x.

62. Carrim AJI, Barbosa EC, Viera JDG (2006) Enzymatic activity of endophytic bacterial isolates of Jacaranda decurrens Cham. (Corobinha-do-campo). Brazilian Archives of Biology and Technology 49 (3): 353 - 359.

63. Cho KM, Hong SY, Lee SM et al. (2007) Endophytic bacteria communities in ginseng and their antifungal activity against pathogens. Microbial Ecology 54 (2): 341 - 351. doi: 10.1007/s00248-007-9208-3.

64. Ma L, Cao YH, Cheng MH et al. (2013) Phylogenetic diversity of bacterial endophytes of Panax notoginseng with antagonistic characteristics towards pathogens of root-rot disease complex. Antonie van Leeuwenhoek 103 (2): 299 - 312. doi: 10.1007/s10482-021-9810-3.

65. Sun H, He Y, Xiao Q et al. (2013) Isolation, characterization, and antimicrobial activity of endophytic bacteria from Polygonum cuspidatum. African Journal of Microbiology Research 7 (16): 1496 - 1504. doi: 10.5897/AJMR12.899.

66. Souza SA, Xavier AA, Costa MR et al. (2013) Endophytic bacteria diversity in banana 'Prata Ana' (Musa spp.) roots. Genetics and Molecular Biology 36 (2): 252 - 264. doi: 10.1590/S1415-47572013000200016.

67. Moat AG, Foster JW, Spector MP (2002) Microbial physiology. 4th Edition. New York, John Wiley and Sons, Inc. Publication.

68. Magnani GS, Didonet CM, Cruz LM et al. (2010) Diversity of endophytic bacteria in Brazilian sugarcane. Genetics and Molecular Research 9 (1): 250 - 258. doi: 10.4238/vol9-1gmr.

69. de Melo Pereira GV, Magalhaes KT, Lorenzetti ER et al. 
(2012) A multiphasic approach for the identification of endophytic bacterial in strawberry fruit and their potential for plant growth promotion. Microbial Ecology 63 (2): 405 - 417. doi: 10.1007/s00248-011-9919-3.

70. Thomas P, Soly TA (2009) Endophytic bacteria associated with growing shoot tips of banana (Musa sp.) cv. Grand Naine and the affinity of endophytes to the host. Microbial Ecology 58 (4): 952 - 964. doi: 10.1007/s00248-009-9559-z.
71. Xia Y, DeBolt S, Dreyer J et al. (2015) Characterization of culturable bacterial endophytes and their capacity to promote plant growth from plants grown using organic or conventional practices. Frontier in Plant Science 6: 490. doi: 10.3389/fpls.2015.00490.

72. Triana E (2005) Phylogenetic analyses of rhizobia isolated from Aeschynomene spp. Biodiversitas Journal of Biological Diversity 6 (4): 233 - 237. 
This page is intentionally left blank. 